\title{
Research on Training Mode of Construction Management Personnel Fuyong Huang ${ }^{1}$ \\ ${ }^{1}$ Liaoning Jianzhu Vocational University, Liaoyang, Liaoning, 111000 73691468@163.com
}

Keywords: Management Personnel; Training Model; Development of Construction Industry

\begin{abstract}
As a pillar industry of Chinese national economy, the construction industry has made great strides. But building construction issue has become increasingly prominent and the number of deaths in the mining industry in the construction industry in 2011 exceeded the coal mining enterprises, ranking No.1. This is not only caused heavy lose of themselves and also has a serious impact on the development of the industry. This paper analyzes the causes of construction enterprises producing high incidence of accidents in which the deeper reason is a sense of leadership at all levels of business, production and management personnel at all levels of lack of knowledge, awareness behind. Meanwhile, the construction site is currently engaged in building management staff mostly related to the management of civil engineering or engineering graduate students, and these students at the school learn the basics have not received knowledge building and health education. Therefore, for this situation, the paper training universities actively explore construction management personnel and particularly important.
\end{abstract}

\section{Introduction}

Today's unprecedented fierce competition in the construction market, any market participant can not survive and develop in a closed single environment, competition from competition in the development of the construction market as a single multi-industry cross-industry competition. Construction companies and actively explores and practice of project management thinking and advanced technology, is the key to gain advantage in the fierce market competition. Therefore, the construction enterprises should actively explore, to practice, to strengthen project management personnel training, in order to occupy a dominant position in the future market competition ready.

\section{Concepts of Training Mode}

In 1994, the former State Board of Education in the "Education for the 21st Century teaching contents and curriculum reform plan," the term first appeared in training mode, but did not explain and define this term. In 1998, the training model presented in the Ministry of Education issued "on deepening reform, need training to adapt to the 21st century, high-quality advice talent" as: a school building knowledge, ability, quality structure for the students, and the achievement of such a structure the way it defines the fundamental characteristics of personnel training and focus reflects the ideas and concepts of education. Since then the concept of domestic scholars on "training mode" is eyes of the beholder wise see wisdom,

US and British personnel training mode, do not pay attention directly meet the engineering needs of special education or vocational education, but is committed to the development of discipline, training within the field of science and engineering innovative talents for the purpose of generalist training mode. Means first giving them the necessary time undergraduate culture humanities, social sciences and natural sciences basics, the basics are not set up for professional and closely, but to train them to have the basic quality of life, given their future participation in the production, research basic knowledge and basic skills needed, on this basis, then give the necessary expertise to meet the needs of a variety of career choices. Its characteristics are carried out extensive relationship discipline of knowledge-based education, basic knowledge and expertise loose. Massachusetts Institute of Technology in the United States as an example, the goal is: to train students with the basic principles of using a solid all-round insight, look natural and social 
phenomena of ability, tireless study habits and strict and systematic study ways to ensure that students in future business improvement and personal growth.

American University undergraduate class of general settings according to faculties, and with changes in the socio-economic development and change, so its specialty emphasize liberal education has obvious characteristics. Set on the basis of the generalist more flexible major, minor or double degree system, and emphasized the comprehensive multidisciplinary and cross. A German Universities are set up according to the technical and engineering disciplines professional, but its coverage is very wide. Such as the Department of Mechanical Engineering University of Aachen contain the mechanical engineering, precision instruments and mechanical design, automotive engineering, energy engineering, chemical engineering, biological engineering, aviation, transportation engineering, plastics and textile engineering and other professional direction. Students can choose a professional direction changes according to socio-economic development and their hobbies.

\section{The Importance of Project Management Personnel Training}

With the deepening of enterprise reform, as construction companies are facing from labor-intensive to technology-based enterprise change management, project management has gradually become the core components, and the core competitiveness of construction enterprises is hidden knowledge and skills contained in the core components in this sense that the core competitiveness of enterprises in fact is a source of competitive advantage, will this core competence into a competitive advantage, we need certain conditions.

In today's increasingly competitive construction market, construction companies are faced with rare opportunities for development, while also facing severe challenges, the construction market competition, risks growing urbanization has brought the difficult construction market opportunities while also accelerated the integration of the construction market construction market survival of the fittest has brought new momentum and spread the flow of talent, promote the construction of a new market allocation of talent structure adjustment process powerful construction enterprises with strong capital and technological advantages in attracting talent resources to maintain a certain advantage, has the ability to participate in the competition, and only cultivate good grasp of human resources and organization, firmly grasp and make good use of important strategic opportunities, focus on the future, solid foundation, optimizing structure, improving quality, and accelerating the development of , in order to win in the competition initiative.

\section{Personnel Training Project Management Mode}

Learn from Foreign Cooperation to Improve The Quality of Talent. With the deepening of China's opening up and actively carry out cooperation and exchanges with foreign institutions, drawing on advanced foreign management experience to improve their project management level, improve the quality of talent in the cooperation, after all, a way of self-promotion. By working to make the project management of foreign investment projects both in line with international project management practices, but also to follow the requirements of laws, regulations and procedures of the project construction. The reality of foreign advanced project management experience and a combination of engineering construction, project management successfully applied to foreign investment project. Learning and practice of such foreign cooperation and can exercise and train a number of high-quality project management personnel.

Carry out the Project Management Knowledge Training, and Strive to Create a Learning-Oriented Enterprises. Competition among construction enterprises in the final analysis is the talent competition. Talents requires businesses to invest in training, in this sense, the future of the most competitive companies will be a learning-oriented enterprises. Practice has proved that the new policy, new norms, new technologies, new things and new project management business in our learning ability test. With the progress and development of society, one study not adapt to business and personal development, lifelong learning should become employees of Learning. Therefore, the 
construction enterprises should strive to create a learning-oriented enterprise, talent continued to carry out multi-channel multi-level knowledge and training. You can invite experts in related fields of project management, project management professors teach knowledge. Such as pre-management and cost control, project construction and technical knowledge, construction project financial management, so that project managers are familiar with the laws, regulations, economic and technical means to master a variety of modern and market information, and constantly expand their knowledge, improve the knowledge structure, in order to improve their overall quality and management level, for enterprises to carry out the project management business foundation.

Project Management Talent Reserves. Project management knowledge across professional surface are relatively wide, project management personnel can be divided into three categories: First, high intelligence compound talents. They are the leader in project management, project manager organizers namely; the second is the professional and technical personnel. They are the middle forces in project management, it is responsible for the various professions; the third is the professional assistants. They are the basic strength of project management, it is a specific operator. For construction companies, it should be at different levels to set up a business talent pool for the project management business conduct reserve personnel in all aspects. Thus, in order to at all stages of project management in a timely manner as needed with the appropriate professionals to ensure the normal development of the project management business.

Strengthen Management, Enhance Understanding, Focusing on Effectiveness. Project construction works one by technology and on the management, with the construction technology matures, the role of management has become increasingly prominent, the father of modern management. Peter Drucker incisively expounded the essence of management: management is a practice, by its very nature is not known but that line; its verification is not logical, but in the results; its only authority is the achievement. Project management effectiveness is good or bad, the most direct profit project, profit is a necessary condition for the survival of enterprises, the profits as the body needs oxygen, water and blood, as without them, there would be no life above profit pursuit. Is the fundamental purpose of project management is a necessary condition for the survival of the majority of employees to the interests of the staff as the fundamental starting point, so they really were involved in the project management, the effectiveness of their wages and project management organic combination of great mobilize their enthusiasm

To improve the professional level of employees, the construction enterprises should be sent to service personnel attend the annual construction workers, quality of training staff, information staff of different positions, so that they work in the professional knowledge and experience good integration, through training and training new people new jobs, the formation of staff in different positions or demoted, more than one post competition mechanism into the project management team not long college staff, honed through practical work, so that they have the ability to work independently, working in project management give full play to the professional theoretical expertise, project department other employees get support and help, and soon realize the transformation of identity and role of the Stanford University School of Business won the Distinguished Teaching Award, James Collins pointed out that enterprises should make the clock, rather than build, the clock is made establish a mechanism so that the company can survive and develop in the market by the strength of the organization, without having to rely on what someone accidentally, product or opportunity, etc. With the further improvement and standardization of the construction market, project management must increasingly rely on a good mechanisms, including good organization, a good evaluation and examination system, good management, project management system through the establishment of the Performance Appraisal System, in the practice of project management and effective operation, for the sake of employees with company interests, to achieve Management of the project to achieve the desired effect

\section{Conclusion}

Talents project construction enterprises is to ensure that the core competitiveness, only pay attention to the importance of project management personnel, train project management talent and 
retain project management talent, can we achieve sound and rapid development.

\section{Acknowledgements}

Project Name: construction engineering management professional production and teaching combined with the training mode of talents

Project level: Liaoning Province Vocational Technical Education Institute of scientific research planning project

Project number: LZY15561

\section{References}

[1] Levitt R E,Parker H W. Reducing Construction Accidents-Top Management's Role. Journal of Construction Division 1976.1023:465 478.

[2] Hinze J, Harrison C. Safety Programs in Large Construction Firms. Journal of Construction Division.1981,1073:455 467.

[3] Hinze J, Figone L A. Subcontractor Safety as Influenced by General Contractors On Small and Medium Sized Projects. Source Document 38, Construction Industry Inst., Univ. of Washington, Seattle, Wash, 1988.

[4] Henan No.5 Construction Company. Estimate of Safety Cost and Labor Protection Investment on Site. Construction Safety in Chinese,1999 2:41 46. 